\title{
EIGHTH ANNUAL REPORT OF THE BRANDON JUNIORS' NEST-BOX PROJECT, 1968
}

by Brian Cutforth, Creighton Blvd., Brandon, Manitoba

Cur club has continued with great success in the nest-box project. We built up our total to 1850 boxes and hope to make this 2,000 by the end of this year. Two new nest lines were established this year: 62 boxes were set out between Neepawa and Ste. Rose, and 50 were set out between Griswold and a point south of Clariere, Manitoba.

Again this year the Mountain Bluebirds increased wonderfully, while the scarcer Eastern Bluebirds hardly exceeded their 1967 total of first-brood nests.

Vandalism is still the worst problem, and we lost about 20 bluebird broods from this cause. A rare case of a chipmunk invading the nest of an Eastern Bluebird (Blue Jay, 26: 145 ) was noted. We also observed both a Mountain Bluebird female and an Eastern Bluebird female caring for their families with no male bird in evidence.

The following totals for the year 1968 will show how the nest project has built up from the 11 boxes set out in 1959 , or from the totals shown in our first report to Blue Jay $(20: 45)$ for 1961 , when no bluebirds were recorded out of 121 nests.

Mountain Bluebird - 242 first - brood nests.

Eastern Bluebird - 60 first-brood nests.

Tree Swallow-an est. 1200 nestings. House Wrens-an est. 20 nestings.

House Sparrows - a few.

The 12 duck nest-boxes in the Rackham area were not checked this summer.

\section{REPORT ON NEST-BOX SUCCESSES IN THE INDIAN HEAD AREA FOR 1968}

by Lorne Scott, Indian Head, Saskatchewan

This past spring I put up another 100 birdhouses to bring my total to over 500. Most of the new boxes were placed in an easterly direction along the old No. 1 Highway between Indian Head and Broadview. Mr. John Lane and the Brandon Junior Bird Club of Brandon, Manitoba have extended their houses west to Broadview. Thus we have now completed a bluebird trail from Indian Head, Saskatchewan to Brandon, Manitoba.

The first Mountain Bluebird of the season arrived at Indian Head on March 5, 1968 and was seen by my brothers Glen and Brian near our farm-yard. This is the earliest spring record for this species in the Indian Head area. Previously, the earliest arrival date was March 12, 1966.

Due to the early spring, the Mountain Bluebirds nested about a week earlier than is usual. They had another successful nesting season as there were 51 nests, from which 218 young were fledged. Last year 24 nest boxes were used by bluebirds.

The main cause of nesting failure of bluebirds and Tree Swallows appears to be the destruction of their eggs by House Wrens. At least 12 nests were destroyed this year in this way. House Wrens nested in 43 houses and produced about 230 young. The number of houses occupied by them was about the same as last year (1967) despite the fact that there were 100 additional houses put up. I believe that this is mainly due to the fact that the last 100 houses were placed farther away from trees than the previous houses. House Wrens seldom venture beyond 100 yards from the nearest cover of trees and shrubs.

The number of houses occupied by Tree Swallows has increased greatly 